\title{
Efektivitas E-Portofolio Berbantuan Edmodo Terhadap Keaktifan Belajar dan Kreativitas Mahasiswa Pada Matakuliah Desain Grafis
}

\author{
Nurbani $^{1}$, Ryan Permana ${ }^{2}$ \\ ${ }^{1,2}$ Program Studi Pendidikan Teknologi dan Komputer, IKIP PGRI Pontianak \\ email:nurbani05@gmail.com ${ }^{1}$, ryanpermana.hidayat@gmail.com ${ }^{2}$
}

(Received: 24 Oktober 2020 / Accepted: 30 November 2020 / Published Online: 20 Desember)

\begin{abstract}
Abstrak
Pemanfaatan portofolio berbasis kertas yang telah dilaksanakan pada matakuliah Desain Grafis, diketahui bahwa keaktifan dan kreativitas mahasiswa masih rendah. Hal ini dapat terlihat dari hasil desain atau karya mahasiswa masih sangat sederhana. Tujuan dari penelitian ini yaitu untuk mengetahui efektivitas E-portofolio dengan berbantuan Edmodo terhadap aktivitas dan kreatifitas mahasiswa. Metode yang digunakan dalam penelitian ini adalah eksperimen dan bentuk penelitian yaitu quasiexperiment (eksperimen semu). Populasi dalam penelitian ini ada 4 kelas. Sampel dalam penelitian ini ada dua kelas yaitu kelas A (kelas kontrol) dengan jumlah 28 mahasiswa dan kelas D (kelas eksperimen) dengan jumlah 26 mahasiswa untuk tahun ajar 2019/2020. Teknik Sampel yang digunakan yaitu Purposive Sampling. Desain eksperimen yang digunakan adalah Posttest Only Control Group Desain. Teknik analisis data yang digunakan yaitu independent sample t-test. Hasil temuan kami menunjukkan bahwa kelas eksperimen memiliki keaktifan dan kreativitas yang lebih baik dengan berbantuan Edmodo dari pada kelas kontrol dengan portofolio berbasis kertas. Terdapat perbedaan keaktifan belajar dan kreativitas mahasiswa yang memanfaatkan e-portofolio menggunakan Edmodo dengan keaktifan belajar mahasiswa yang memanfaatkan portofolio berbasis kertas pada matakuliah Desain Grafis.
\end{abstract}

Kata kunci: Aktivitas, Efektivitas, E-portofolio, Kreativitas.

\begin{abstract}
Using paper-based portfolios (PBP) that have been implemented in the Graphic-Design course, it was known that students' activeness and creativity were low yet. It can be seen from the results of the design or student worked were still very simple. The purpose of this study is to determine the effectiveness of E-portfolios assisted by Edmodo on student activities and creativity. The method used in this research is an experiment, and the form of research is a quasi-experiment (quasiexperimental). The population in this study was four classes. The sample in this study consisted of two classes, namely class A (control class) with a total of 28 students and class $D$ (experimental class) with a total of 26 students for the 2019/2020 school year. The sampling technique used is Purposive Sampling. The experimental design used was Post-test Only Control Group Design. The data analysis technique used is the independent sample t-test. Our findings show that the experimental class has better activeness and creativity with Edmodo then the control class with paper-based portfolios. There are differences in learning activeness and creativity of students who utilize e-portfolios thought Edmodo and active learning of students who use PBP in Graphic-Design courses.
\end{abstract}

Keywords: Activities, Effectiveness, E-portfolio, Creativity

\section{PENDAHULUAN}

Penilaian dan evaluasi adalah usaha untuk mengumpulkan data yang kemudian diolah untuk pengambilan kebijakan suatu program pendidikan (Sani, 2014). Dalam kegiatan belajar mengajar, guru melakukan penilaian dengan mengumpulkan fakta dan dokumen belajar peserta didik untuk melakukan perbaikan perencanaan pembelajaran. Oleh sebab itu, kegiatan 
penilaian proses dan hasil belajar membutuhkan informasi yang bervariasi dari setiap peserta didik atau kelompok peserta didik. Assessment yang tepat dapat memberikan refleksi peristiwa pembelajaran yang dialami oleh peserta didik.

Salah satu asesmen yang dapat digunakan adalah portofolio. Portofolio merupakan laporan hasil karya mahasiswa sebagai hasil pelaksanaan proses pembelajaran. Portofolio dibuat secara berterusan untuk memantau perkembangan mahasiswa. Untuk mengukur kemampuan atau kompetensi mahasiswa dapat menggunakan portofolio. Isi dari Portofolio yaitu hasil pelaksanaan proses pembelajaran setiap pertemuan yang disusun dalam bentuk laporan berdasarkan jangka waktu tertentu. Untuk penyusunan portofolio disesuaikan dengan tujuan pembelajaran dan jenis kegiatan yang dillakukan.

Selain portofolio ada juga e-portofolio yang digunakan berbasis digital. Portofolio lebih bersifat tradisional yaitu berupa kertas (paper-based) seperti pekerjaan siswa dalam bentuk kertas dan menggunakan binder. Sedangkan e-portofolio dalam bentuk digital atau elektronik yang berupa file. Perkembangan teknologi maka format portofolio saat ini berkembang menjadi elektronik portofolio (Wargahadibrata, Ibrahim, \& Hirmana, 2016). Potensi dari eportofolio sama besar dengan potensi portofolio konvensional hanya melalui e-portofolio sifat dinamis teknologi akan menyertai format ini.

Portofolio adalah suatu sistem yang dirancang untuk keperluan pengelolaan datadata hasil karya mahasiswa dengan penerapan teknologi komputer baik hardware maupun software, sehingga seluruh proses kegiatan dapat terkelola menjadi informasi yang bermanfaat dalam pengelolaan E-Portofolio hasil karya mahasiswa (Fernando, Anharudin, \& Fadli, 2018). Adapun kesimpulan dari e-portofolio yaitu bentuk digital dari portofolio dimana pekerjaan peserta didik dapat terbaca melalui komputer dalam bentuk PDF, CD, DVD dan website. E-portofolio membutuhkan keahlian peserta didik dalam menyusunnya karena dapat memuat unsur multimedia disesuaikan dengan bentuk tugas dari e-portofolio tersebut. Jika dibandingkan dengan portofolio tradisional, e-portofolio memiliki beberapa kelebihan diantaranya mudah diakses, berorientasi pada peserta didik serta dapat menciptakan peserta didik yang kreatif dan komunikatif

Beberapa mata kuliah praktikum dosen telah menerapkan portofolio dalam pembelajaran di PTIK, salah satunya adalah mata kuliah Desain Grafis yaitu berupa laporan hasil pembelajaran disetiap pertemuan praktikum. Mahasiswa membuat portofolio mengikuti aturan format yang telah ditentukan oleh dosen dengan menulis di buku jurnal dan hasil karya desain di print out dan ditempel di buku jurnal tersebut pada setiap pertemuan. Nama portofolio tersebut dikenal dengan portofolio berbasis kertas. Beberapa kekurang memerlukan banyak waktu dan penilaian portofolio memerlukan tempat penyimpanan yang memadai apalagi jika jumlah mahasiswa cukup besar (Irawan, Astra, \& Bakri, 2012)

Berdasarkan hasil wawancara pada pengampu mata kuliah Desain Grafis, diketahui bahwa keaktifan dan kreativitas mahasiswa masih rendah. Hal ini dapat diketahui dari masih adanya mahasiswa dalam pengumpulan portofolio melebih batas janka waktu yang telah ditetapkan pengampu matakuliah Desain Grafis. Selain itu ditemukan hasil portofolio mahasiswa yang tidak sesuai dengan tugas yang diberikan dosen.

Portofolio dalam bentuk digital disebut juag elektronik portofolio atau e-portofolio. Untuk mengakses E-portofolio harus menggunakan jaringan internet. Dengan E-portofolio akan mempermudah bagi dosen dan mahasiswa kapan saja dan dimana saja. Kemudahan lainnya yaitu dosen dapat mengawasi mahasiswa yang terlambat dalam pengumpulan laporan e-portofolio.

Sistem e-learning semakin berkembang dan telah diimplementasikan di berbagai institusi pendidikan di dunia. Siswa dapat belajar mandiri dengan penggunaan e-learning sebagai media pembelajaran, sehingga akitivitas siswa menjadi pusat dalam pembelajaran. Pembelajaran dengan menggunakan eLearning menuntut siswa untuk lebih mandiri dalam 
belajar, dengan demikian pembelajaran dengan e-learning dapat meningkatkan aktivitas siswa (Purwaningsih, Rosidin, \& Wahyudi, 2014). E-learning ini telah mengubah cara belajar mengajar tradisional lewat tatap muka diruang kelas menjadi pembelajaran berbasis online (Wahyudi, 2017). Menurut (Suryati, 2017) pemanfaatan teknologi computer dalam pembelajaran online dapat memberikan penguatan dan tidak dibatasi oleh ruang dan waktu (Pop, 2003) mengungkapkan bahwa Edmodo adalah virtual learning environment yang aman, gratis, membantu siswa dan guru untuk terhubung dan berkolaborasi diluar jam tatap muka. Adapun beberapa fitur di dalam Edmodo yaitu bahan ajar, penugasan, quiz, pengumuman, polling, planner dan badge. Pembelajaran dengan Edmodo menuntut mahasiswa untuk aktif dan mandiri sedangkan dosen berperan sebagai fasilitator.

Tujuan dari penelitian ini yaitu untuk mengetahui efektivitas E-portofolio dengan berbantuan Edmodo terhadap aktivitas dan kreatifitas mahasiswa. Mahasiswa dapat mengumpulkan e-portofolio di Edmodo dan juga dapat mengakses bahan ajar di edmodo. Untuk mendorong mahasiswanya lebih aktif dan lebih kreatif dalam mendesain, dosen memberikan fitur lencana atau bagde sebagai bentuk penghargaan kepada mahasiswa yang berprestasi. Selain itu dapat mendorong kreatifitas hasil karya desain yang dibuat mahasiswa atas prestasi yang dicapainya.

\section{METODE}

Adapun metode yang digunakan dalam penelitian ini adalah eksperimen. Bentuk penelitian ini adalah quasi eksperimental designt. (Sugiyono, 2011) menyatakan bahwa ciri utama dari quasi experimental design adalah pengembangan dari true experimental design, yang mempunyai kelompok kontrol namun tidak dapat 35 berfungsi sepenuhnya untuk mengontrol variabel-variabel dari luar yang mempengaruhi pelaksanaan eksperimen. Desain eksperimen yang digunakan dalam penelitian ini adalah Posttest Only Control Group Desain yang nampak pada tabel 1 .

\begin{tabular}{|c|c|c|}
\hline Kelompok & Perlakuan & Posttest \\
\hline Eksperimen & $\mathrm{X}$ & $\mathrm{O}$ \\
\hline Kontrol & - & $\mathrm{O}$ \\
\hline
\end{tabular}

(Sugiyono, 2011)

Variabel penelitian ini menggunakan variabel bebas dan variabel terikat. Variabel bebas yaitu pembelajaran e-portofolio dan variabel terikat yaitu keaktifan dan kreativitas mahasiswa. Populasi adalah keseluruhan jumlah mahasiswa pada semester 2 pada Program Studi P.TIK. Sampel penelitian ini yaitu kelas A dan kelas D tahun ajar 2019/2020 untuk dijadikan sebagai kelas eksperimen (D) dan kelas control (A). Teknik pengambilan sampel yaitu purposive sampling yang dilakukan non random terhadap sampelnya. Alat pengumpulan data yang digunakan berupa nonn-tes (bukan tes). Instumen penelitian ini nantinya dijadikan sebagai alat pengumpulan data. Instrument dalam penelitian ini yaitu angket keaktivan dan angket kreativitas mahasiswa. Pengujian validitas isi dilakukan dengan pendapat dari ahli (judgment experts) dan dibantu dengan kisi-kisi instrumen. Untuk mengetahui reliabilitas tes tersebut maka digunakan rumus Spearman-Brown. Sebelum uji hipotesis dilakukan uji normalitas dan homogenitas. Setelah uji normalitas dan uji homogenitas terhadap data hasil penelitian, maka langkah selanjutnya adalah melakukan uji hipotesis. Penelitian ini menggunakan uji Independent Sample T-test 


\section{HASIL DAN PEMBAHASAN \\ Hasil}

Adapun data penelitian akan dibahas yaitu data posttest kreaktifan dan kreativitas mahasiswa. Tujuannya untuk mendeskripsikan kepada pembaca mengenai deskripsi data yang didapat peneliti. Data keaktifan belajar dan kreativitas mahasiswa diperoleh melalui angket tertutup. Untuk mengetahui keaktifan belajar mahasiswa digunakan 14 butir pernyataan dan kreativitas mahasiswa 17 butir pernyataan. Data-data dari angket kemudian diolah menggunakan SPSS untuk mendapatkan rerata, standar deviasi, skor maksimum dan skor minimum. Untuk deskripsinya bisa dilihat pada tabel 2.

Tabel 2. Deskripsi Keaktifan Belajar Mahasiswa

\begin{tabular}{ccccc}
\hline Kelompok & Mean & Std. Dev & Min & Max \\
\hline Kelas Ekperimen & 54,77 & 5,799 & 42 & 65 \\
Kelas Kontrol & 46,46 & 6,021 & 33 & 58 \\
\hline
\end{tabular}

Berdasarkan tabel 2, diperoleh skor keaktifan rata-rata kelompok eksperimen adalah 54,77 dengan skor minimum 42 dan skor maksimum 65. Sedangkan pada kelompok kontrol, skor keaktifan rata-rata sebesar 46,46 dengan skor minimum 33 dan skor maksimum 58 . Dilihat dari skor rata-rata kelas eksperimen lebih tinggi dari pada skor rata-rata kelas kontrol. Ini menunjukkan bahwa kelas eksperimen memiliki keaktifan lebih baik dengan berbantuan Edmodo dari pada kelas kontrol

Tabel 3. Deskripsi Kreativitas Mahasiswa

\begin{tabular}{ccccc}
\hline Kelompok & Mean & Std. Dev & Min & Max \\
\hline Kelas Ekperimen & 62,42 & 5,573 & 53 & 72 \\
Kelas Kontrol & 58,32 & 4,473 & 50 & 67 \\
\hline
\end{tabular}

Berdasarkan tabel 3, diperoleh skor kreativitas rata-rata kelompok eksperimen adalah 62,42 dengan skor minimum 53 dan maksimum 72. Sedangkan pada kelompok kontrol, skor kreativitas rata-rata sebesar 58,32 dengan skor minimum 50 dan skor maksimum 67. Dilihat dari skor rata-rata kelas eksperimen lebih tinggi dari pada skor rata-rata kelas contro. Ini menunjukkan bahwa kelas eksperimen memiliki kreativitas lebih baik dengan berbantuan Edmodo dari pada kelas kontrol

Sebelum uji prasyarat dilakukan uji normalitas dan homogenitas. Kegunaannya untuk melihat data berdistribusi normal atau tidak. Sedangkan uji homogenitas untuk melihat pengujian mengenai sama tidaknya variansi-variansi dua buah distribusi atau lebih. Uji normalitas yang digunakan adalah statistik uji Kolmogrov Smirnov menggunakan bantuan program SPSS 16.0. Hasil uji normalitas data penelitian ini terdapat pada tabel berikut.

Berdasarkan tabel 4 data berdistribusi normal adalah signifikansi (p) $>\alpha$, dimana $\alpha=$ 0,05. Hasil uji data posttest pada tabel diatas diperoleh nilai sig. lebih besar dari 0,05 sehingga data berdistribusi normal. Uji homogenitas dilakukan untuk mengetahui apakah data mempunyai varians homogen atau tidak. Pengujian ini menggunakan uji Levene dengan bantuan program SPSS 16.0. Hasil uji homogenitas terhadap data posttest dapat dilihat pada tabel 5 . 
Tabel 4. Hasil Uji Normalitas

\begin{tabular}{cccc}
\hline Data & sig & $\boldsymbol{\alpha}$ & Kesimpulan \\
\hline Keaktifan belajar kelas eksperimen & 0,847 & 0,05 & Normal \\
Keaktifan belajar kelas control & 0,973 & & Normal \\
Kreativitas belajar kelas eksperimen & 0,648 & & Normal \\
Kreativitas belajar kelas control & 0,970 & & Normal \\
\hline
\end{tabular}

Tabel 5. Hasil Uji Homogenitas

\begin{tabular}{cccc}
\hline Data & sig & alpha & Kesimpulan \\
\hline $\begin{array}{c}\text { Keaktifan belajar kelas eksperimen dan } \\
\text { kelas kontrol }\end{array}$ & 0,459 & 0,05 & Homogen \\
$\begin{array}{c}\text { Kreativitas belajar kelas eksperimen } \\
\text { dan kelas control }\end{array}$ & 0,216 & & Homogen \\
\hline
\end{tabular}

Pengujian hipotesis penelitian dilakukan karena data berdistribusi normal dan memiliki varians homogeny. Uji hipotesis yang digunakan menggunakan rumus Independent sample ttest. Syarat hipotesis diterima jika nilai sig (2-tailed) lebih kecil dari 0,005, hipotesis ditolak jika nilai sig (2-tailed) lebih besar dari 0,005. Hasil perhitungan dengan bantuan SPSS 16.0 dapat dilihat pada tabel 6.

Tabel 6. Hasil Uji-t Keaktifan Belajar

\begin{tabular}{ccccccc}
\hline Variabel & F & sig & $\mathbf{t}$ & $\begin{array}{c}\text { Sig. (2- } \\
\text { tailed) }\end{array}$ & $\begin{array}{c}\text { Mean } \\
\text { difference }\end{array}$ & $\begin{array}{c}\text { Std. Error } \\
\text { Difference }\end{array}$ \\
\hline Keaktifan & 0,557 & 0,459 & 3,106 & 0,003 & 5,420 & 1,745 \\
\hline
\end{tabular}

Berdasarkan pada tabel 6, diperoleh nilai sig (2-tailed) yaitu 0,003 lebih kecil dari pada 0,005 sehingga dapat disimpulkan Ha diterima dan Ho ditolak. Ini dapat diartikan bahwa terdapat perbedaan keaktifan belajar mahasiswa yang memanfaatkan e-portofolio menggunakan Edmodo dengan keaktifan belajar mahasiswa yang memanfaatkan portofolio berbasis kertas pada matakuliah Desain Grafis. Selanjutnya, berdasarkan tabel 7, diperoleh nilai sig (2-tailed) yaitu 0,004 lebih kecil dari pada 0,005 sehingga dapat disimpulkan Ha diterima dan Ho ditolak. Ini dapat diartikan bahwa terdapat perbedaan kreativitas mahasiswa yang memanfaatkan e-portofolio menggunakan Edmodo dengan kreativitas belajar mahasiswa yang memanfaatkan portofolio berbasis kertas pada matakuliah Desain Grafis.

Tabel 7. Hasil Uji-t Kreativitas Belajar

\begin{tabular}{ccccccc}
\hline Variabel & $\mathbf{F}$ & sig & $\mathbf{t}$ & $\begin{array}{c}\text { Sig. (2- } \\
\text { tailed) }\end{array}$ & $\begin{array}{c}\text { Mean } \\
\text { difference }\end{array}$ & $\begin{array}{c}\text { Std. Error } \\
\text { Difference }\end{array}$ \\
\hline Kreativitas & 1.571 & .216 & 2.993 & .004 & 4.10165 & 1.37035 \\
\hline
\end{tabular}

\section{Pembahasan}

Berdasarkan hasil penelitian dilihat dari data deskripsi skor keaktifan rata-rata kelompok eksperimen adalah 54,77 dan kelompok kontrol skor keaktifan rata-rata sebesar 46,46. Ini menunjukkan bahwa kelas eksperimen memiliki keaktifan lebih baik dengan berbantuan Edmodo dari pada kelas kontrol dengan portofolio berbasis kertas. Hal ini dapat dilihat dari ketepatan waktu dalam pengumpulan tugas laporan praktikum, mahasiswa membuat laporan praktikum sesuai dengan panduan praktikum, mahasiswa aktif dalam memberikan pendapat atau komentar di Edmodo mengenai hasil desain yang mereka buat, dan tugas yang dikerjakan sesuai dengan langkah-langkah praktikum. Untuk kelas kontrol 
mahasiswa terkadang masih terlambat dalam pengumpulan laporan praktikum. Terkadang mahasiswa kurang begitu aktif dalam bertanya mengenai tugas yang diberikan. mahasiswa atau materi yang dosen berikan.

Untuk skor kreativitas rata-rata kelompok eksperimen adalah 62,42 sedangkan kelompok kontrol, skor kreativitas rata-rata sebesar 58,32. Ini menunjukkan bahwa kelas eksperimen memiliki kreativitas lebih baik dengan berbantuan Edmodo dari pada kelas kontrol dengan berbasis kertas. Hasil postingan desain yang mahasiswa buat ditampilkan di Edmodo sehingga mahasiswa dapat melihat dan memberikan komentar yang positif. Hal ini memberikan semangat atau motivasi kepada mahasiswa untuk membuat desain sekreatif mungkin untuk mendapatkan nilai yang lebih baik. Selain itu dosen akan memberikan lencana atau badge kepada mahasiswa yang memiliki desain yang menarik dan penuh kreativitas sebagai bentuk penghargaan kepada mahasiswa. Sedangkan untuk kelas kontrol kreativitas mahasiswa masih belum maksimal dan terkadang belum begitu rapi dalam mendesain suatu objek. Pengetahuan mahasiswa dalam mendesain masih dasar dan perlu belajar lagi dalam mempelajari tool-tools yang ada pada aplikasi desain grafis.

Berdasarkan hasil uji hipotesis keaktifan belajar mahasiswa diperoleh bahwa nilai sig (2-tailed) yaitu 0,003 lebih kecil dari pada 0,005 sehingga dapat disimpulkan Ha diterima dan Ho ditolak. Ini dapat diartikan bahwa terdapat perbedaan keaktifan belajar mahasiswa yang memanfaatkan e-portofolio menggunakan Edmodo dengan keaktifan belajar mahasiswa yang memanfaatkan portofolio berbasis kertas pada matakuliah Desain Grafis. Hal ini sejalan dengan penelitian yang dilakukan oleh (Fikri, 2014) bahwa keaktifan siswa yang memanfaatkan e-portofolio menggunakan Edmodo lebih tinggi daripada portofolio berbasis kertas.

Hasil uji hipotesis kreativitas belajar mahasiswa dalam penelitian ini diperoleh bahwa nilai sig (2-tailed) yaitu 0,004 lebih kecil dari pada 0,005 sehingga dapat disimpulkan Ha diterima dan Ho ditolak. Ini dapat diartikan bahwa terdapat perbedaan kreativitas belajar mahasiswa yang memanfaatkan e-portofolio menggunakan Edmodo dengan keaktifan belajar mahasiswa yang memanfaatkan portofolio berbasis kertas pada matakuliah Desain Grafis. Sebelum menggunakan e-portofolio mahasiswa membuat desain yang masih sederhana dan terkadang masih belum rapi dalam membuat mengedit atau memanipulasi suatu objek. Dengan adanya e-portofolio dengan berbantuan Edmodo mahasiswa mendesain hasil kreativitasnya lebih baik karena setiap desain mahasiswa diposting di Edmodo dan hasil kreativitas desain mahasiswa diberi penghargaan oleh dosen berupa lencana atau badge sebagai bentuk motivasi mahasiswa. Mahasiswa berlomba-lomba dalam membuat desain untuk memperoleh penghargaan dari dosen dan memperoleh nilai yang lebih baik. Penelitian ini sebelumnya pernah dilakukan oleh (Basya \& Khairul, 2017) dengan hasil temuan media $e$ portofolio tematik terpadu berbasis web blog yang dikembangkan dapat menumbuhkan kreativitas mahasiswa calon guru SD.

\section{SIMPULAN}

Kelas eksperimen memiliki keaktifan lebih baik dengan berbantuan Edmodo dari pada kelas kontrol dengan portofolio berbasis kertas. Kelas eksperimen memiliki kreativitas lebih baik dengan berbantuan Edmodo dari pada kelas kontrol dengan berbasis kertas. Terdapat perbedaan keaktifan belajar mahasiswa yang memanfaatkan e-portofolio menggunakan Edmodo dengan keaktifan belajar mahasiswa yang memanfaatkan portofolio berbasis kertas pada matakuliah Desain Grafis.Terdapat perbedaan kreativitas belajar mahasiswa yang memanfaatkan e-portofolio menggunakan Edmodo dengan keaktifan belajar mahasiswa yang memanfaatkan portofolio berbasis kertas pada matakuliah Desain Grafis 


\section{REFERENSI}

Abdullah, S. R. (2014). Pembelajaran Saintifik untuk Kurikulum 2013. Jakarta. Bumi Aksara. Aries, E. (2011). Asesmen dan Evaluasi (2nd ed.). Malang. Aditya Media Publishing.

Arikunto, S. (2002). Prosedur Penelitian Suatu Pendekatan Praktek (Rev). Kakarta. PT. Rineka Cipta.

Aroma, D. (2015). Pengaruh Asesmen E-Portofolio Melalui Group facebook Menggunakan Model Pembelajaran Arias Terhadap Hasil Belajar. Jurnal Pendidikan Fisika, 4(1), 6977.

Basya, A., \& Khairul, M. (2017). Pengembangan E-portofolio Tematik-Terpadu Berbasis Web Blog untuk Menanamkan Karakter Kritis dan Kreatif melalui Pembelajaran IPA. Jurnal Pendidikan MIPA, 7(2), 30-39

Fernando, D., Anharudin, \& Fadli. (2018). Rancang Bangun Aplikasi E-portofolio Hasil Karya Mahasiswa UNSERA Menggunakan Metode Scrum. Jurnal Sistem Informasi, $5(1), 7-12$.

Fikri, K. (2014). Pengembangan E-Portofolio Dalam Project Based Learning Pada Mata Kuliah Animal Physiology Pada Program Studi Pendidikan Biologi. Jurnal Ilmiah Dosen, 3(2), 17-24.

Ibrahim, N., \& Wargahadibrata, R. A. H. (2016). Pemetaan Fungsi Platforn E-Portofolio Untuk Perkuliahan di Jurusan Kurikulum dan Teknologi Pendikan Fakultas llmu Pendidikan Universitas Negeri Jakarta. JTP - Jurnal Teknologi Pendidikan, 18(3), 202214.

Irawan, D., Astra, I.M., Bakri, F. (2012). Pengaruh Penerapan Penilaian Portofolio Online Web Based Learning Terhadap Hasil Belajar Fisika Siswa Tingkat SMA. Jurnal Teknodik, 16(2), 299-316.

Pop, A. (2003). Edmodo E-Portofolios in ELF - A Case Study. International Conference on Virtual Learning ICVL, 337-341. Romania: University Bucharest.

Purwaningsih, R., Rosidin, U., \& Wahyudi, I. (2014). Pengaruh Penggunaan E-Learning dengan Schoology terhadap Hasil Belajar Perserta Didik. Jurnal Pembelajaran Fisika Universitas Lampung, 1(5), 51-61.

Sugiyono. (2011a). Metode Penelitian Kuantitatif, Kualitatif dan R\&D (3rd ed.). Bandung. Alfabeta.

Sugiyono. (2011b). Metode Penelitian Pendidikan Pendekatan Kuantitatif, Kualitatif dan $R \& D .1$ st ed.). Bandung. Alfabeta.

Suryati. (2017). Sistem Manajemen Pembelajaran Online Melalui E-Learning. Jurnal UIN, $6(1), 60-76$.

Wahyudi, I. (2017). Pengembangan Program Pembelajaran Fisika SMA Berbasis E-Learning dengan Schoology. Jurnal Ilmiah Pendidikan Fisika Al-Biruni, 6(2), 187-199 